\title{
$\emptyset$ ker komplikasjoner under svangerskap og fødsel risikoen for schizofreni?
}

\author{
Sammendrag \\ Bakgrunn. Schizofreni er en alvorlig \\ psykisk lidelse med ukjent etiologi. \\ Arvelighet er den viktigste risikofakto- \\ ren. Pre- og perinatale komplikasjo- \\ ner/traumer har i flere studier vist \\ sammenheng med økt risiko for \\ å utvikle schizofreni i voksen alder. \\ Hensikten med denne artikkelen er å gi \\ et overblikk over forskningen som \\ omhandler pre- og perinatale kompli- \\ kasjoner som risikofaktor ved schizo- \\ freni.
}

Materiale og metode. Denne oversiktsartikkelen er basert på ikke-systematiske litteraturs $\varnothing \mathrm{k}$ i PubMed og Embase.

Resultater. Den antatte sammenhengen mellom pre- og perinatale komplikasjoner og økt risiko for schizofreni har vært studert i snart 80 år. Maternell infeksjon linfluensa, rubella, toksoplasmose), prenatal malnutrisjon samt fødselskomplikasjoner som lav fødselsvekt og asfyksi, har i en rekke pasient-kontroll-studier blitt assosiert med økt risiko for schizofreni. Dyreforsøk har vist at pre- og perinatal eksponering for hypoksi og maternell inflammasjonsrespons kan påvirke nevronal utvikling. Underliggende patofysiologiske mekanismer og eventuell interaksjon med sårbarhetsgener for schizofreni er ikke klarlagt.

Fortolkning. Det er mye som tyder på at det er en sammenheng mellom preog perinatale komplikasjoner og risiko for schizofreni.
Artikkelen er en omarbeidet utgave av en artikkel på nettstedet Schizofreniforum i 2007 (1)

\section{Unn Kristin Haukvik}

unn.haukvik@medisin.uio.no

Ingrid Agartz

Institutt for psykiatri

Universitetet i Oslo

Postboks 85 Vinderen

0319 Oslo

Schizofreni er en alvorlig psykisk lidelse som rammer $0,5-0,8 \%$ av befolkningen (2). Etiologien har lenge vært diskutert. Den viktigste risikofaktoren er genetisk sårbarhet, og i de senere år har en rekke kandidatgener for sykdommen blitt foreslått (3). Samtidig har studier vist at miljøfaktorer som cannabisbruk, sosial migrasjon, urbanitet og høy alder hos far kan ha en sammenheng med utvikling av lidelsen (4-6). Mye tyder på at genesen ved schizofreni delvis er nevroutviklingsrelatert, der ulike pre- og perinatale komplikasjoner/traumer kan være av betydning (7-9). At føtale forhold kan påvirke risiko for bl.a. diabetes og hjerte- og karsykdommer i voksen alder, er velkjent (10-12). Det synes imidlertid å være mindre kjent at det kan være en sammenheng mellom preog perinatale komplikasjoner og økt risiko for schizofreni. Vi ønsker med denne artikkelen å gi et innblikk i forskningen på dette feltet.

\section{Materiale og metode}

Artikkelen er basert på ikke-systematiske litteratursøk i PubMed og Embase. Vi selekterte artiklene ut ifra at de var relatert til forekomst av schizofreni hos voksne og at en eller flere pre- og/eller perinatale komplikasjoner ble evaluert. Relevante pasientkontroll-studier, epidemiologiske studier og enkelte dyreforsøk ble inkludert. Orginalartikler som var tilgjengelig elektronisk eller i Bibliotek for medisin og helsefag ved Universitetet i Oslo, er inkludert. Artiklene ble sjekket for relevante kryssreferanser.

Førsteforfatter skriver for tiden doktorgrad om sammenhengen mellom obstetriske komplikasjoner og hjernestruktur ved schizofreni. Andreforfatter er professor i psykiatri ved Universitetet i Oslo og har over 20 års forskningserfaring innen biologisk psykiatri, primært fra Karolinska Institutet.

\section{Historikk}

Allerede i 1934 utførte Rosanoff og kolleger en studie av 142 tvillingpar der en eller begge av tvillingene hadde schizofreni, for å kartlegge arveligheten ved sykdommen (13). Et av bifunnene i denne studien var at fødselstraumer som tangforløsning og for tidlig fødsel kunne ha sammenheng med senere utvikling av schizofreni. I 1956 lanserte Parsamanick og medarbeidere hypotesen om at det eksisterer et kontinuum av utfall ved pre-, peri- og postnatale skader, fra de alvorligste, som abort og dødfødsel, til mildere utfall som atferdsproblemer og schizofreni (14). I 1966 ble det påvist at pasienter med schizofreni hadde lavere fødselsvekt enn sine søsken (15), et gjennombrudd som medførte økt interesse for feltet.

Høyrisikogruppestudier av barn av mødre med schizofreni i 1970-årene antydet at fødselskomplikasjoner i kombinasjon med genetisk disposisjon ga økt risiko for schizofreni (16). Forskningsinteressen økte ytterligere da man i 1987 fikk et teoretisk rammeverk i form av en nevroutviklingshypotese for schizofreni (9). Denne hypotesen ble blant annet basert på at man hos pasienter med schizofreni fant økt forekomst av preog perinatale komplikasjoner, manglende tegn på degenerative hjerneforandringer post mortem og økt forekomst av mindre fysiske anomalier av embryonal opprinnelse (7).

På tross av stor forskningsaktivitet de senere årene, kliniske pasient-kontroll-studier, MR-studier og store registerbaserte studier, er pre- og perinatale komplikasjoners betydning for etiologien ved schizofreni fremdeles ikke klarlagt. Dette kan ha flere årsaker. Rent metodologisk er det vanskelig å registrere forekomst av slike komplikasjoner retrospektivt. Det er også vanskelig å skille effekten av ulike risikofaktorers påvirkning pre- og perinatalt. For eksempel kan lav fødselsvekt ha flere årsaker (dårlig ernæring, sviktende placentafunksjon, mors røyking, genetiske faktorer m.m.). I tillegg er tidspunktet for når komplikasjonen inntreffer, avgjørende for hvilken type skade den kan gjøre på fosterets hjerne. I historisk sammenheng var det flere alvorlige fødselskomplikasjoner før, men moderne svanger-

\section{Hovedbudskap}

- Pre- og perinatale komplikasjoner kan henge sammen med økt risiko for schizofreni

- De underliggende patofysiologiske mekanismene er ukjente 
skaps-, fødsels- og neonatalomsorg har på sin side gjort at flere barn enn tidligere overlever alvorlige komplikasjoner.

\section{Pre- og perinatale komplikasjoner \\ Maternell underernæring}

Mot slutten av den annen verdenskrig oppsto alvorlig matmangel i Vest-Nederland, hvilket medførte underernæring også hos gravide (17). Blant barn født av mødre som var gravide, spesielt i første trimester, under denne tidsavgrensede (februar-mai 1945) og godt dokumenterte perioden er det blitt påvist økt prevalens av schizofreni sammenliknet med barn født før og etter (relativ risiko 2,0) (17). I en annen studie der mødrene var gravide under den kinesiske hungersnøden i 1959-61, ble det også påvist økt forekomst av schizofreni (relativ risiko 2,3). Ettersom sultperioden varte så lenge som et par år, kunne det ikke påvises en sammenheng mellom risiko for schizofreni og underernæring under bestemte perioder av svangerskapet (18).

\section{Maternell infeksjon}

Serumanalyser av influensaantigen ved bruk av nedfryst serum fra svangerskapene til kvinner som nå har voksne barn med schizofreni, har påvist en sju ganger økt risiko for schizofreni ved maternell influensa i første trimester (19). Økt risiko for utvikling av schizofreni er også blitt rapportert ved maternell toksoplasmose og rubellainfeksjon (20). I forsøk på mus har man demonstrert at maternell inflammasjonsrespons kan medføre endret genekspresjon og mediere skadelig effekt på fosterets hjerneutvikling enten direkte eller via påvirkning av placentafunksjon $(21,22)$. Det at flere infeksjonsagens (influensa, toksoplasmose, rubella) er blitt vist å ha sammenheng med økt risiko for schizofreni, støtter at det kan være faktorer ved den maternelle inflammasjonsresponsen som bidrar til den økte risikoen. Prenatal eksponering for influensainfeksjon hos mor er også blitt brukt som forklaring på den epidemiologisk beskrevne økte risikoen for schizofreni hos barn født på senvinteren/ våren $(23)$.

\section{Obstetriske komplikasjoner}

Flere epidemiologiske studier har vist at det er en sammenheng mellom ulike obstetriske komplikasjoner og risiko for schizofreni. Vi presenterer her et lite utvalg. I en svensk registerstudie av 3942 personer fant Hultman og medarbeidere en økt risiko for schizofreni hos barn av mødre som hadde fått diagnostisert blødning fra uterus/placenta under svangerskap/fødsel, hos gutter med lav fødselsvekt samt hos sønner av kvinner med stor multiparitet (barn nr. 4 og oppover; hvilket ikke er en komplikasjon i seg selv, men kan være en risikofaktor for obstetriske komplikasjoner) (23).

I en meget grundig svensk studie der registerdata ble kombinert med fødselsjourna- ler $(\mathrm{N}=1567)$, fant Dalman og medarbeidere en sterk sammenheng mellom tegn på asfyksi ved fødselen og senere utvikling av schizofreni (OR 4,5, $95 \%$ KI 2,2-9,5 etter justering for andre obstetriske komplikasjoner, forekomst av psykose hos mor og sosial klasse) (24). Funnet ble delvis replikert i en dansk registerstudie $(\mathrm{N}=25865)$, der det ble påvist en signifikant sammenheng mellom forekomst av hypoksi samt prematuritet og maternell infeksjon og økt risiko for schizofreni, kontrollert for psykisk lidelse i familien og sosioøkonomisk status (25).

I en finsk studie av en fødselskohort fra $1966(\mathrm{~N}=11$ 017) påviste Jones og medarbeidere en sammenheng mellom utvikling av schizofreni og lav fødselsvekt $(<2500 \mathrm{~g})$ samt kombinasjonen av lav fødselsvekt og fødsel før svangerskapsuke 37 (26). Lav fødselsvekt $(<2500 \mathrm{~g})$ var også signifikant relatert til schizofreniutvikling i en svensk registerbasert studie av 5680 tvillingpar (inkludert 88 med schizofreni). Funnet var også signifikant blant 90 tvillingpar som var diskordante for schizofreni, og der den friske tvillingen var kontrollperson (27). I en norsk studie av 20 tvillingpar, diskordante eller konkordante for schizofreni, fant Onstad og kolleger ikke sammenheng mellom lav fødselsvekt og utvikling av schizofreni (28).

Sosiodemografiske faktorer kan ha sammenheng med økt frekvens av pre- og perinatale komplikasjoner. Det er blitt beskrevet en sammenheng mellom økt forekomst av arbeidsløshet, tenåringsfødsler, alenemødre og mangel på sosial støtte og obstetriske komplikasjoner hos mødre med schizofren (29). Det er også påvist økt forekomst av dødfødsel og neonatal spedbarnsdød hos kvinner med psykoselidelser (30). Barn av kvinner med schizofreni kan således se ut til å ha økt risiko for sykdommen både via arv og via økt forekomst av pre- og perinatale komplikasjoner hos deres mødre.

\section{Komplikasjonenes virkning \\ Det kliniske bildet}

Det er gjort relativt få studier av sammenhengen mellom det å ha vært utsatt for preog perinatale komplikasjoner og det kliniske bildet ved schizofreni. Enkelte studier, inkludert en metaanalyse av 854 schizofrenipasienter, har påvist en sammenheng mellom pre- og perinatale komplikasjoner og tidligere sykdomsdebut (31-33), men negative funn er også rapportert (34). Det er blitt beskrevet at flere menn enn kvinner med schizofreni har vært utsatt for pre- og perinatale komplikasjoner (35), noe man i den ovenfornevnte metaanalysen ikke fant holdepunker for (33). En overvekt av negative symptomer (affektavflatning, viljeløshet, fattig tankeinnhold) er beskrevet hos de av pasientene som i tillegg til en genetisk risiko for schizofreni også hadde vært utsatt for alvorlige pre- og perinatale komplikasjoner (36). I en annen studie ble det vist at schizo- frenipasienter med overveiende negativ psykotisk symptomatologi hadde lavere apgarskår ved fødselen enn dem som hovedsakelig hadde positive psykotiske symptomer (vrangforestillinger, hallusinose) (37).

\section{Forandringer i hjerneanatomi}

Strukturelle hjerneforandringer som forstørrede ventrikler, redusert volum av temporallappen (38) og redusert kortikal tykkelse prefrontalt og temporalt (39) er blitt rapportert fra MR-studier av pasienter med schizofreni. Noen av forandringene kan påvises før sykdomsdebut (40). Volumet av hippocampus og av cortex har i dyremodeller (henholdsvis rotte og sau) vist seg sårbare for pre- og perinatal hypoksisk skade $(41,42)$. Schizofrenipasienter som har vært utsatt for føtal hypoksi hadde $i$ en studie mindre kortikal grå substans, spesielt temporalt, sammenliknet med pasienter som ikke hadde vært utsatt for føtal hypoksi (43). Likeledes har man vist at ulike pre- og perinatale komplikasjoner er relatert til mer uttalt forstørrede laterale ventrikler (43-45) og enda mindre hippocampusvolum (45-47) enn hva som er påvist i schizofrenigruppen som helhet. Funnene fra MR-studiene styrker hypotesen om at schizofreni er relatert til forstyrrelser i nevroutvikling (9).

\section{Gen-miljø-interaksjon}

At arvelig disposisjon i kombinasjon med pre- og perinatale komplikasjoner gir statistisk økt risiko for å utvikle schizofreni, ble vist allerede i 1970-årene (16). De senere års kartlegging av sårbarhetsgener for schizofreni har gjort det mulig å teste gen-miljøinteraksjon på molekylærbiologisk nivå. Foreløpig er det kun gjort én studie, der det ble vist en statistisk interaksjonseffekt mellom alvorlige pre- og perinatale komplikasjoner og variasjon i enkeltnukleotidpolymorfismer (single nucleotide polymorphisms, SNPs) i hypoksiregulerte schizofrenisårbarhetsgener, med økt risiko for schizofreni som konsekvens (48). Ettersom mange av de pre- og perinatale komplikasjonene kan forårsake føtal hypoksi, kan en slik interaksjon være biologisk plausibel (49). Pre- og perinatale komplikasjoner, spesielt maternell infeksjon og underernæring, kan også tenkes å påvirke epigenetiske prosesser (som for eksempel DNA-metylering), som vil kunne medvirke til subtile avvik i bla. nevronal cellemigrasjon og i nevronenes cytoarkitektur (50). Epigenetiske modifikasjoner kan føre til fenotypiske endringer mange år etter at de først fant sted, ettersom genene de modifiserer kan være sårbare for miljømessige (12) eller hormonelle (50) påvirkninger senere i livet, jf. tidsvinduet mellom fosterliv og sykdomsdebut ved schizofreni.

\section{Konklusjon}

Mange studier viser at det er en sammenheng mellom det å ha vært utsatt for ulike prenatale og/eller perinatale komplikasjoner 
og det å utvikle schizofreni i voksen alder. Ettersom de fleste som har vært utsatt for disse komplikasjonene ikke utvikler schizofreni, og langt fra alle pasienter med schizofreni har vært utsatt for pre- og perinatale komplikasjoner, er denne sammenhengen ikke direkte. Imidlertid kan pre- og perinatale komplikasjoner gjennom interaksjon med genetisk disposisjon og/eller andre miljøfaktorer bidra til økt risiko for schizofreni.

Vi mener det er viktig at obstetrikere og barneleger er klar over at denne sammenhengen er rapportert og at det pågår stor internasjonal forskningaktivitet for å kartlegge de underliggende patofysiologiske mekanismene.

Forfatterne ønsker å takke professor Thomas McNeil, Avdeling for psykiatrisk epidemiologi, Lunds universitet, Sverige, for nyttige kommentarer til manuskriptet.

\section{Oppgitte interessekonflikter: Ingen}

\section{Litteratur}

1. Schizofreniforum. www.schizofreniforum.org (26.11.2007).

2. Saha S, Chant D. Welham J et al. A systematic review of the prevalence of schizophrenia. PLoS Med 2005; 2: e141.

3. Stefansson H, Ophoff RA, Steinberg $\mathrm{S}$ et al. Common variants conferring risk of schizophrenia. Nature 2009: 460: 744-7.

4. Degenhardt L, Hall W. Is cannabis use a contributory cause of psychosis? Can J Psychiatry 2006; 51 556-65

5. Cantor-Grae E. The contribution of social factors to the development of schizophrenia: a review of recent findings. Can J Psychiatry 2007; 52: 277-86.

6. Byrne M, Agerbo E, Ewald $\mathrm{H}$ et al. Parental age and risk of schizophrenia: a case control study. Arch Gen Psychiatry 2003; 60: 673-8.

7. Rapoport JL, Addington AM, Frangou S et al. The neurodevelopmental model of schizophrenia: update 2005. Mol Psychiatry 2005; 10: 434-49

8. Marenco S, Weinberger DR. The neurodevelopmental hypothesis of schizophrenia: following a trail of evidence from cradle to grave. Dev Psychopatol 2000; 12: 501-27.

9. Weinberger DR. Implications of normal brain development for the pathogenesis of schizophrenia. Arch Gen Psychiatry 1987: 44: 514-7.

10. Iliadou A, Cnattingius S, Lichtenstein P. Low birthweight and type-2 diabetes: a study on 11162 swedish twins. Int J Epidemiol 2004; 33: 948-53.

11. Vangen S, Nordhagen R, Lie KK. Gjensyn med Forsdahl-Barker hypotesen. Tidsskr Nor Lægeforen 2005: 125: 451-3.

12. Gluckman PD, Hanson MA, Cooper C et al. Effect of in utero and early-life conditions on adult health and disease. N Engl J Med 2008: 359: 61 -73.

13. Rosanoff AJ, Handy LM, Plesset IR et al. The etiology of so-called schizophrenic psychoses: with special reference to their occurrence in twins. Am J Psychiatry 1934: 91: 247-86.

14. Pasamanick B, Rogers ME, Lilienfeld AM. Pregnancy experience and the development of behavior disorder in children. Am J Psychiatry 1956; 112: 613-8.

15. Lane EA, Albee GW. Comparative birth weights of schizophrenics and their siblings. J Psychol 1966. 64: 227-31.

16. Mednick SA, McNeil TF. Current methodology in research on etiology of schizophrenia: serious difficulties which suggest the use of the high-risk group method. Psychol Bull 1968; 70: 681-93.

17. Hoek HW, Brown AS, Susser E. The dutch famine and schizophrenia spectrum disorders. Soc Psychiatry Psychiatr Epidemiol 1998; 33: 373-9.

18. St Claire D, Xu M, Wang P et al. Rates of adult schizophrenia following prenatal exposure to the
Chinese famine of 1959-1961. JAMA 2005: 294: 557-62

19. Brown AS, Begg MD, Gravenstein S et al. Serologic evidence of prenatal influenza in the etiology of schizophrenia. Arch Gen Psychiatry 2004; 61: 774-80.

20. Brown AS. Prenatal infection as a risk factor for schizophrenia. Schizophr Bull 2006; 32: 200-2.

21. Smith SE, Li J, Garbett K et al. Maternal immune activation alters fetal brain development through interleukin-6. J Neurosci 2007; 27: 10695-702.

22. Fatemi SH, Folsom TD, Reutiman TJ et al. Prenatal viral infection of mice at E16 causes changes in gene expression in hippocampus of the offspring. Eur Neuropsychopharmacol 2009; 19: 648-53.

23. Hultman CM, Sparén P. Takei N et al. Prenatal and perinatal risk factors for schizophrenia, affective psychosis, and reactive psychosis of early onset: a case-control study. BMJ 1999: 318: 421-6.

24. Dalman C, Thomas HV, David AS et al. Signs of asphyxia at birth and risk of schizophrenia. Population-based case-control study. Br J Psychiatry 2001; 179: 403-8.

25. Byrne M, Agerbo E, Bennedsen B et al. Obstetric conditions and risk of first admission with schizophrenia: a Danish national register based study. Schizophr Res 2007; 97: 51-9.

26. Jones PB, Rantakallio P. Hartikainen AL et al. Schizophrenia as a long term outcome of pregnancy, delivery, and perinatal complications: a 28 year follow-up of the 1966 north Finland general population birth cohort. Am J Psychiatry 1998; 155: 355-64.

27. Nilsson E, Stålberg G, Lichtenstein P et al. Fetal growth restriction and schizophrenia: A Swedish twin study. Twin Res Hum Genet 2005; 8: 402-8.

28. Onstad S, Skre I, Torgersen S et al. Birtweight and obstetric complications in schizophrenic twins. Acta Psychiatr Scand 1992; 85: 70-3.

29. Jablensky AV, Morgan V, Zubrik SR et al. Pregnancy, delivery and neonatal complications in a population cohort of women with schizophrenia and major affective disorders. Am J Psychiatry 2005; 162: 79-91

30. Howard LM, Goss C, Leese M et al. Medical outcome of pregnancy in women with psychotic disorders and their infants in the first year after birth. Br J Psychiatry 2003; 182: 63-7.

31. Cannon TD, Rosso IM, Hollister JM et al. A prospective cohort study of genetic and perinatal influences in the etiology of schizophrenia. Schizophrenia Bulletin 2000; 26: 351-66.

32. Matsumoto H, Takei N, Saito F et al. The association between obstetric complications and child hood onset schizophrenia: a replication study. Psychol Med 2001: 31: 907-14.

33. Verdoux H, Geddes JR, Takei et al. Obstetric complications and age at onset in schizophrenia: An international collaborative meta-analysis of individual patient data. Am J Psychiatry 1997; 154: $1220-7$

34. Walshe M, McDonald C, Taylor M et al. Obstetric complications in patients with schizophrenia and their unaffected siblings. Eur Psychiatry 2005; 20: 28-34.

35. Kirov G, Jones PB, Harvey I. Do obstetric complications cause the earlier age at onset in male than female schizophrenics? Schizophr Res 1996; 20: $117-24$

36. Cannon TD, Mednick SA, Parnas J. Antecedents of predominantly negative- and predominantly positive-symptom schizophrenia in a high-risk popula tion. Arch Gen Psychiatry 1990; 47: 622-32.

37. Kotlicka-Antczak M, Gmitrowicz A, Sobów TM et al. Obstetric complications and apgar score in earlyonset schizophrenic patients with prominent positive and prominent negative symptoms. J Psychiatr Res 2001; 35: 249-57.

38. Honea R, Crow TJ, Passingham D et al. Regional deficits in brain volume in schizophrenia: a metaanalysis of voxel-based morphometry studies. Am J Psychiatry 2005; 162: 2233-45.

39. Nesvåg R, Lawyer G, Varnäs K et al. Regional thinning of the cerebral cortex in schizophrenia: Effects of diagnosis, age and antipsychotic medication. Schizophr Res 2008; 98: 16-28.

40. Pantelis C, Velakoulis D, McGorry PD et al. Neuroanatomical abnormalities before and after onset of psychosis: a cross-sectional and longitudinal MRI comparison. Lancet 2003; 361: 281-8.
41. Boksa P. Animal models of obstetric complications in relation to schizophrenia. Brain Res Rev 2004; 45: 1-17.

42. Rees S, Harding R, Walker D. An adverse intrauterine environment: implications for injury and altered development of the brain. Int J Dev Neurosci 2008; 26: 3-11.

43. Cannon TD, van Erp TG, Rosso IM et al. Fetal hypoxia and structural brain abnormalities in schizophrenic patients, their siblings and controls. Arch Gen Psychiatry 2002; 59: 35-41.

44. Falkai P, Schneider-Axmann T, Honer WG et al. Influence of genetic loading, obstetric complications and premorbid adjustment on brain morphology in schizophrenia. Eur Arch Psychiatry Clin Neurosci 2003; 253: 92-9.

45. McNeil TF, Cantor-Graae E, Weinberger DR. Relationship of obstetric complications and differences in size of brain structures in monozygotic twin pairs discordant for schizophrenia. Am J Psychiatry 2000; 157: 203-12.

46. Schulze K, McDonald C, Frangou S et al. Hippocampal volume in familial and nonfamilial schizophrenic probands and their unaffected relatives. Biol Psychiatry 2003; 53: 562-70.

47. van Erp TG, Saleh PA, Rosso IM et al. Contribution of genetic risk and fetal hypoxia to hippocampal volume in patients with schizophrenia or schizoaffective disorder, their unaffected siblings, and healthy volunteers. Am J Psychiatry 2002; 159: 1514-20.

48. Nicodemus KK, Marenco S, Batten SJ et al. Serious obstetric complications interact with hypoxiaregulated/vascular-expression genes to influence schizophrenia risk. Mol Psychiatry 2008; 13 $873-7$.

49. Schmidt-Kastner R, van Os J, W M Steinbusch $\mathrm{H}$ et al. Gene regulation by hypoxia and the neurodevelopmental origin of schizophrenia. Schizophr Res 2006; 84: 253-71.

50. Petronis A. Schizophrenia, neurodevelopment and epigenetics. I: Keshavan M, Kennedy J, Murray R. Neurodevelopment and schizophrenia. Cambridge: Cambridge University Press, 2004: 174-91.

Manuskriptet ble mottatt 30.5. 2008 og godkjent 26.11. 2009. Medisinsk redaktør Trine B. Haugen. 